\title{
Prevalence of Hepatitis B and Hepatitis C in Tertiary Care Center of Northeren India
}

\author{
Parveen Malhotra*, Vani Malhotra, Pushkar, Usha Gupta and Yogesh Sanwariya \\ Department of Medical Gastroenterology, Microbiology, Gynecology \& Obstetrics, PGIMS, Rohtak \& DGHS Haryana, India
}

Submission: April 13, 2020; Published: August 10, 2020

*Corresponding author: Parveen Malhotra, Department of Medical Gastroenterology, Microbiology, Gynecology \& Obstetrics, PGIMS, Rohtak \& DGHS Haryana, 128/19, Civil Hospital Road, India

Abstract

Introduction: Hepatitis B surface Antigen (HbsAg) positivity in the general population ranges from $1.1 \%$ to $12.2 \%$, with an average prevalence of 3-4\%. Anti-Hepatitis C virus (HCV) antibody prevalence in the general population is estimated to be between $0.09-15 \%$. Based on some regional level studies, it is estimated that in India, approximately 40 million people are chronically infected with Hepatitis B and 6-12 million people with Hepatitis C.

Objective: To estimate prevalence of Hepatitis B and Hepatitis C at tertiary care center of Northern India.

Methods: This study was conducted at Medical Gastroenterology Department at PGIMS, Rohtak in collaboration with Microbiology Department. It was a retrospective year wise analysis of data of five years pertaining to total number of patient samples sent from various outdoor patient department \& indoor wards and out of them who were found positive for HbsAg or Anti HCV antibody on Enzyme linked immunosorbent assay (ELISA) test. In total, two lakh two hundred and eighteen $(2,00,218)$ samples for HbsAg and two lakh thirteen thousand four hundred and six $(2,13,406)$ for anti HCV antibody were tested over a period of five years.

Results: On retrospective analysis of five years, the yearly prevalence of $\mathrm{HbsAg}$ ranged between $3.16 \%-8.1 \%$ with mean of $5.23 \%$ which is higher in comparison to other parts of India where usually it has been reported to around $4 \%$. In case of anti HCV antibodies it ranged between $4.03 \%-7.54 \%$ with mean of $5.18 \%$ which is also greater than expected in India.

Conclusion: Haryana, in Northern India has become a prominent hub of Hepatitis B \& Hepatitis C in India and prevalence of both of them is almost same i.e. $5.23 \%$ and $5.18 \%$ respectively, thus needs more dedicated efforts for curbing the menace of these deadly diseases.

Keywords: Hepatitis B; Hepatitis C; HbsAg; Anti HCV antibody; ELISA

\section{Introduction}

Viral hepatitis has been now recognized as a major public health problem as it caused 1.34 million deaths in 2015, equivalent to deaths caused by tuberculosis and higher than those caused by HIV [1]. It is estimated that 325 million people worldwide are living with chronic HBV or HCV infection [2]. Viral hepatitis is increasingly being recognized as a public health problem in India. Hepatitis B surface Antigen (HbsAg) positivity in the general population ranges from $1.1 \%$ to $12.2 \%$, with an average prevalence of 3-4\%. Anti-Hepatitis C virus (HCV) antibody prevalence in the general population is estimated to be between $0.09-15 \%$ [3]. Based on some regional level studies, it is estimated that in India, approximately 40 million people are chronically infected with Hepatitis B and 6-12 million people with Hepatitis C [4]. Chronic HBV infection accounts for $40 \%$ of Hepato-cellular Carcinoma (HCC) and 20-30\% cases of cirrhosis in India [3]. Chronic HCV infection accounts for $12-32 \%$ of
HCC and $12-20 \%$ of cirrhosis [3]. India has about 3 million to 9 million persons with active HCV infections [5]. All key and bridge population groups under HIV infections are especially vulnerable to viral hepatitis infections too. There include groups like recipients of multiple blood/ blood products transfusion, patients on hemodialysis, People Who Inject Drugs, Males having sex with males, female sex workers, sexual partners of infected people, prisoners, migrants and truckers etc. Also, high risk population for viral hepatitis include close first degree relatives and family members: mother, siblings, spouse and children, of persons affected with viral hepatitis. The other populations for both hepatitis B and C include those who have received blood or blood products especially before implementation of hepatitis C testing at a large scale in India; i.e. before 2001. Hepatitis B and $\mathrm{C}$ infections have long gestation periods before the disease progresses to advanced stages resulting in liver cirrhosis and liver cancer, resulting in mortality if treatment is not provided in time. 
Hepatitis B infection is caused by HBV DNA (deoxyribonucleic acid) virus which belongs to Hepadnaviridae family and can be either acute or chronic [6,7]. Acute hepatitis B is marked by acute inflammation and hepatocellular necrosis whereas chronic hepatitis B infection is defined as persistent HBV infection, as evidenced by existence of hepatitis B surface antigen [HbsAg] in the blood or serum for longer than six months, with or without associated active viral replication and indication of hepatocellular injury [7]. The risk of chronicity is more in neonates (90\%) and young children $(20-60 \%)$ than in infection that is acquired in adulthood $(5 \%)[8,9]$. There is a serious dearth of data regarding the true prevalence of HBV in India. HbsAg positivity has been reported to range between $2 \%$ and $8 \%$ in most studies [10-12]. The most widely quoted figure of carrier rate in India is $4.7 \%$ with an estimated carrier population of 56.5 million [11]. Many of these studies are based on data from blood banks and may not truly reflect the national prevalence. The prevalence of chronic hepatitis $\mathrm{C}$ virus (HCV) infection has been estimated at between $1.2 \%$ and $1.7 \%$ in the adult global population whereas estimated figure in India is around 1\% but there are no discrete studies for the same. In India, in absence of discrete studies, estimated prevalence rate of hepatitis $\mathrm{C}$ is $1 \%$ [13]. HCV, a single stranded RNA Virus and in acute phase, patients presents clinically with symptoms of generalized Myalgias, nausea, vomiting and upper abdominal discomfort. The patients who develop Chronic hepatitis C, after a gap of ten to twenty years may develop cirrhosis in 5-20 $\%$ of patients and around $25 \%$ of them can advance to End stage liver disease and hepatocellular carcinoma [14]. HCV has seven genotypes 1-7 and in India, genotype 3 is more common in South whereas Genotype 4 is common in North. The initial screening test is Anti HCV antibody test which is confirmed with HCV RNA quantitative, a polymerase chain reaction test [13].

\section{Methods}

This study was conducted at Medical Gastroenterology Department at PGIMS, Rohtak in collaboration with Microbiology
Department. It was a retrospective year wise analysis of data of five years (2015-2019) pertaining to patients whose samples were sent from various outdoor patient departments \& Indoor wards and were found positive for HbsAg or Anti HCV antibody on Enzyme linked immunosorbent assay (ELISA) test. Five milliliter of blood was collected and serum was separated which was divided into two aliquots; one was used for HbsAg and the other was used for anti-HCV antibody for ELISA testing. In total, two lakh two hundred and eighteen $(2,00,218)$ samples for HbsAg and two lakh thirteen thousand four hundred and six $(2,13,406)$ for anti HCV antibody were done over a period of five years.

\section{Observations}

On retrospective analysis of five years, the yearly prevalence of HbsAg ranged between $3.16 \%-8.1 \%$ with mean of $5.23 \%$ which is higher in comparison to other parts of India where usually maximally it has been reported to around 4\%. In year 2015, 35,120 samples sent from various wards and outdoor patients were tested for HbsAg, out of which 1110 (3.16\%) were found to be positive on ELISA testing. Similarly for year 2016,out of 36,790, $1240(3.37 \%)$ were found to be positive, for year 2017, out of $44,770,1926$ (4.30\%) were found to be positive, for year 2018, out of $32,095,2329(7.25 \%)$ were found to be positive, for year 2019 , out of $51443,4205(8.1 \%)$ were found to be positive. In case of anti HCV antibodies yearly prevalence ranged between $4.03 \%$ $7.54 \%$ with mean of $5.18 \%$ which is greater than expected in India where it was thought to be around $1 \%$. In year 2015, 35,116 samples sent from various wards and outdoor patients were tested for anti HCV antibody, out of which 1567 (4.46\%) were found to be positive on ELISA testing. Similarly for year 2016,out of $36,700,2093$ (5.78\%) were found to be positive, for year 2017, out of $41,688,3146(7.54 \%)$ were found to be positive, for year 2018, out of 48,462, 1956 (4.03\%) were found to be positive, for year 2019, out of 51440, 2119 (4.11\%) were found to be positive (Figure 1).

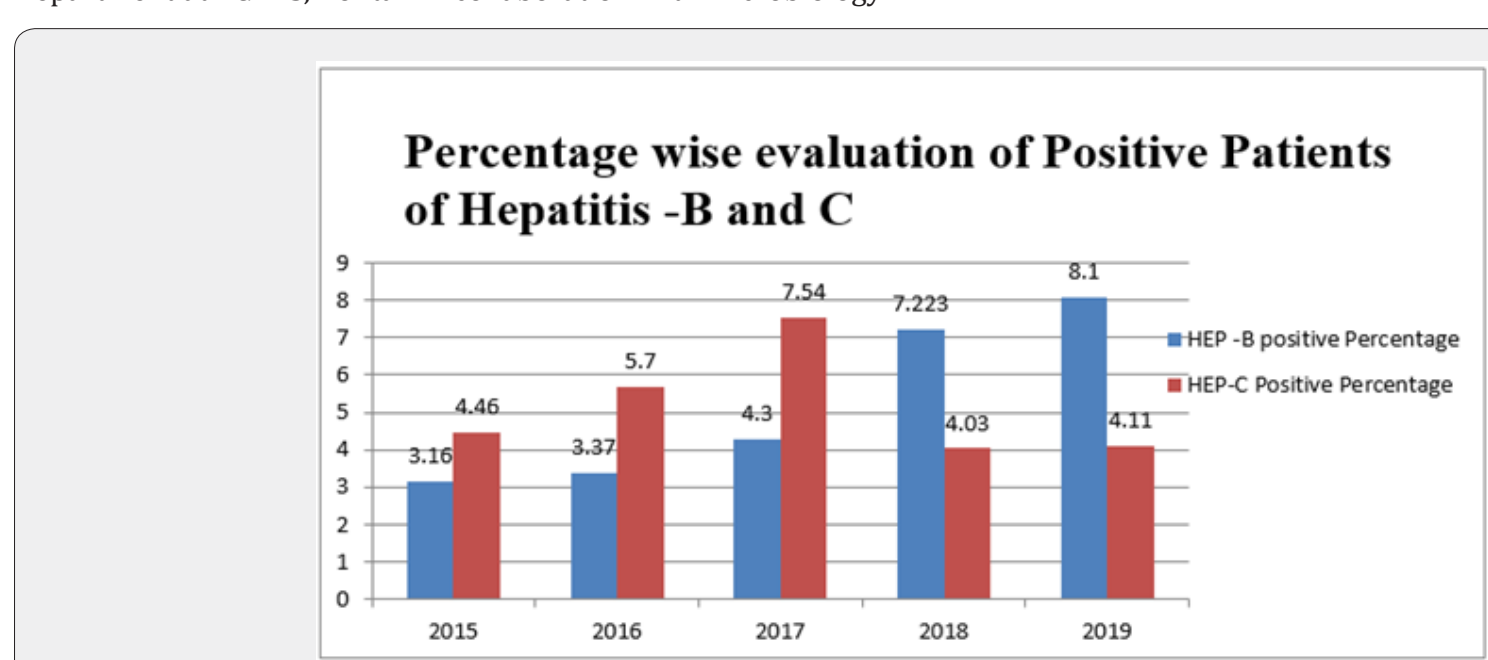

Figure 1: Showing year wise prevalence rate of $\mathrm{HbsAg}$ and anti HCV antibody positivity. 


\section{Discussion}

Though reports on the prevalence of HBV and/or HCV infection among blood donors [15] and in patients with certain clinical conditions [16,17] are available, prevalence among general population in India is sparse.

Study on the prevalence of HBV and HCV infection is needed to understand its epidemiology and to create strategies to improve public health which may help in the disease prevention and control [18]. There is a considerable variation in the geographical distribution of HCV [19]. The overall prevalence of HCV in our study was $5.18 \%$ (5/2291), which is strikingly much higher than study reports from Bangladesh [20] and Tamil Nadu [21]. In India, very few studies are available on the prevalence of HCV in general population. Community based studies from West Bengal [22], Andhra Pradesh [23] and Arunachal Pradesh [24] showed the HCV prevalence of $0.87 \%, 1.4 \%$ and $7.89 \%$ respectively, the first two had lower prevalence in comparison to our study whereas from Arunachal Pradesh had prevalence on higher side.

HBV prevalence in different population has been shown to vary widely from $0.1 \%$ in the developed countries to $20 \%$ in the developing nations [25]. In our study the overall prevalence of HBV was $5.23 \%$. In 1995, the average estimated carrier rate of HBV in India was 4\% [26]. A community based study on HBV prevalence in urban and rural subjects in Tamil Nadu documented $5.7 \%$ of HbsAg positivity [27], which is comparable to our study report. In contrast, studies from West Bengal [28] and Kanpur [25] showed that 2.97\% (227/7653) and 2.25\% (450/20000) were positive for HbsAg, respectively and this is less than which was revealed in our study. The data on the general population prevalence of HBV or HCV are limited in India. In comparison with study reports from India, we have observed overall higher prevalence of HCV and HBV infection.

\section{Conclusion}

Haryana, in Northern India has become a prominent hub of Hepatitis B and Hepatitis C in India and prevalence of both of them is almost same and needs more dedicated efforts for curbing the menace of these deadly diseases. Availability of sufficient recent estimates of HBV or HCV prevalence is necessary to evaluate control measures and health care planning.

\section{References}

1. (2015) Guidelines for the prevention, care and treatment of persons with chronic hepatitis B infection. WHO.

2. (2016) Consolidated guidelines on the use of antiretroviral drugs for treating and preventing HIV infection: recommendations for a public health approach. ( $2^{\text {nd }}$ edn.), WHO.

3. (2016) Guidelines for the screening care and treatment of persons with chronic hepatitis C infection. WHO.

4. WHO (2016) Global Disease estimates 2016. WHO.

5. Central Bureau of Health Intelligence (2016) Ministry of Health and
Family Welfare. National Health Profile. New Delhi, India.

6. R J Lamontagne, S Bagga, M J Bouchard (2016) Hepatitis B virus molecular biology and pathogenesis. Hepatoma Research 2(7): 163.

7. D Lavanchy (2004) Hepatitis B virus epidemiology, disease burden, treatment, arid current and emerging prevention and control measures. Journal of Viral Hepatitis 11(2): 97-107.

8. BJ McMahon (2004) The natural history of chronic hepatitis B virus infection. Seminars in Liver Disease 24(1): 17-21.

9. JH Hoofnagle, E Doo, TJ Liang, R Fleischer, ASF Lok (2007) Management of hepatitis B: summary of a clinical research workshop. Hepatology 45(4): 1056-1075.

10. P Abraham (2012) Viral hepatitis in India. Clinics in Laboratory Medicine 32(2): 159-174.

11. SP Thyagarajan, S Jayaram, B Mohanavalli (1996) Prevalence of HBV in general population of India. in Hepatitis B in India: Problems and Prevention. SK Sarin, AK Singal (Eds.), CBS Publishers and Distributors, New Delhi, India, p. 5-16.

12. (2002) Prevention of Hepatitis B in India-An Overview, World Health Organization South-East Asia Regional Office. New Delhi, India.

13. Parveen Malhotra, Usha Gupta, Suraj Bhan Kamboj, Vani Malhotra, Yogesh Sanwariya (2019) Haryana Model For Treatment And Eliminating Hepatitis C. Journal of Hematology Research 6: 32-34.

14. Ray SC, Thomas DL (2015) Hepatitis C. In: Bennett JE, Dolin R, Blaser MJ, (Eds.), Mandell, Douglas, and Bennett's Principles and Practice of Infectious Diseases, ( $8^{\text {th }}$ edn.), Philadelphia, Pennsylvania: Saunders, USA, pp. 1904-1927.

15. Arora D, Arora B, Khetarpal A (2010) Seroprevalence of HIV, HBV, HCV and syphilis in blood donors in Southern Haryana. Indian J Pathol Microbiol 53(2): 308-309.

16. Ali S, Shukla I, Malik A, Rizvi M, Ajmal MR (2008) Prevalence of HCV and HBV infection in liver disorders in the Aligarh region of western Uttar Pradesh. Indian. J Pathol Microbiol 51(3): 460-461.

17. Mysorekar VV, Rao SG, Mahadeva KC (2008) Liver histology in patients on hemodialysis with chronic hepatitis $\mathrm{C}$ viral infection. Indian J Pathol Microbiol 51(2): 182-185.

18. Krishnasamy Narayanasamy, Chezhian Annasamy, Senthilkumar Ramalingam, Sathishkumar Elumalai (2015) Study of Hepatitis B and C Virus Infection in Urban and rural Population of Tamil Nadu, India. Int J Curr Microbiol App Sci 4(6): 443-451.

19. Saeed U, Waheed Y, Ashraf M (2014) Hepatitis B and hepatitis C viruses: a review of viral genomes, viral induced host immune responses, genotypic distributions and worldwide epidemiology. Asian Pac J Trop Dis 4(2): 88-96.

20. Ashraf H, Alam NH, Rothermundt C, Brooks A, Bardhan P, et al. (2010) Prevalence and risk factors of hepatitis $B$ and $C$ virus infections in an impoverished urban community in Dhaka, Bangladesh. BMC Infect Dis 10: 208.

21. Gowri V, Chandraleka C, Vanaja R (2012) The current seroprevalence of hepatitis $C$ virus in a tertiary care centre in vellore, Tamil Nadu. Indian J Commun Med 37(2): 137.

22. Chowdhury A, Santra A, Chaudhuri S, Dhali GK, Chaudhuri S, et al. (2003) Hepatitis $C$ virus infection in the general population: a community-based study in West Bengal, India. Hepatology 37(4): 802-809.

23. Khaja MN, Madhavi C, Thippavazzula R, Nafeesa F, Habib AM, et al. (2006) High prevalence of hepatitis C virus infection and genotype distribution among general population, blood donors and risk groups. Infect Genet Evol 6(3): 198-204. 
24. Phukan AC, Sharma SK, Das HK, Mahanta J (2001) HCV activity in an isolated community in north east India. Indian J Pathol Microbiol 44(4): 403-405.

25. Behal R, Jain R, Behal KK, Bhagoliwal A, Aggarwal N, et al. (2008) Seroprevalence and risk factors for hepatitis B virus infection among general population in Northern India. Arq Gastroenterol 45(2): 137-140.

26. Tandon BN, Acharya SK, Tandon A (1996) Epidemiology of hepatitis B virus infection in India. Gut 38(Suppl 2): 56-59.
27. Kurien T, Thyagarajan SP, Jeyaseelan L, Peedicayil A, Rajendran P, et al. (2005) Community prevalence of hepatitis B infection and modes of transmission in Tamil Nadu, India. Indian J Med Res 121(5): 670-675.

28. Chowdhury A, Santra A, Chakravorty R, Banerji A, Pal S, et al. (2005) Community-based epidemiology of hepatitis B virus infection in West Bengal, India: prevalence of hepatitis B e antigennegative infection and associated viral variants. J Gastroenterol Hepatol 20(11): 1712-1720.

\section{Your next submission with JuniperPublishers will reach you the below assets}

- Quality Editorial service

- Swift Peer Review

- Reprints availability

- E-prints Service

- Manuscript Podcast for convenient understanding

- Global attainment for your research

- Manuscript accessibility in different formats ( Pdf, E-pub, Full Text, audio)

- Unceasing customer service

Track the below URL for one-step submission https://juniperpublishers.com/online-submission.php 